\title{
MINIMAL ENDOSCOPIC CHANGES IN NON-EROSIVE REFLUX DISEASE
}

\author{
Alterações endoscópicas mínimas na doença do refluxo não erosiva
}

Ana Carolina Ferreira RATIN, Ivan Roberto Bonotto ORSO

From Gastroclínica Cascavel, Cascavel, PR, Brazil.
ABSTRACT - Background: Gastroesophageal reflux disease is an increasingly common condition worldwide causing a considerable economic impact. More than half the patients with clinical symptoms of reflux disease display no mucosal erosions on esophagogastroduodenoscopy, making it impossible to confirm the diagnosis without further investigations. Aim: To evaluate the correlation between minimal endoscopic changes on white-light esophagogastroduodenoscopy (carditis, mucosal thickening and invisibility of vessels) and histologic changes observed in distal esophageal biopsies in a sample of patients with symptoms suggestive of reflux disease, and to verify the specificity of these symptoms for non-erosive reflux disease. Methods: Retrospective, cross-sectional study based on information retrieved from a digital database at a Brazilian hospital for the period MarchOctober, 2012. The sample consisted of previously untreated, non-smoking subjects aged $>18$ years with symptoms suggestive of reflux disease but no esophageal erosions, submitted to esophagogastroduodenoscopy and distal esophageal biopsy. Results: The final sample included 23 subjects. The most frequently observed change was invisibility of vessels $(n=21$; $91.3 \%)$, followed by mucosal thickening $(n=15 ; 65.2 \%)$ and carditis $(n=5 ; 21.7 \%)$. The correlation coefficient between each variable and the anatomopathological diagnosis was 0.386 for body mass index, 0.479 for mucosal thickening, -0.116 for invisibility of vessels, 0.306 for carditis and 0.462 for hiatal hernia. Conclusion: All patients displayed minimal endoscopic changes on esophagogastroduodenoscopy, but only mucosal thickening revealed a moderately significant correlation with severity of esophagitis, although increased body mass index values and the presence of hiatal hernia were also associated.

\section{HEADINGS - Peptic esophagitis.} Gastrointestinal

Gastroesophageal reflux. endoscopy.

\section{Correspondence:}

Ivan Roberto Bonotto Orso

Email: ivan@gastro.com.br

Financial source: none

Conflicts of interest: none

Received for publication: 30/09/2014

Accepted for publication: 11/12/2014

DESCRTORES - Esofagite péptica. Endoscopia gastrointestinal. Refluxo gastroesofágico.
RESUMO - Racional: Doença do refluxo gastroesofágico é condição cada vez mais comum em todo o mundo causando impacto econômico considerável. Mais da metade dos pacientes com sintomas clínicos da doença não apresentam erosões endoscópicas da mucosa, o que torna impossível confirmar o diagnóstico sem outras investigações. Objetivo: Avaliar a correlação entre mudanças mínimas endoscópicas em endoscopia digestiva alta de luz branca (cardite, espessamento da mucosa e invisibilidade de vasos) e as alterações histológicas observadas em biópsias distais de uma amostra de pacientes com sintomas sugestivos de doença do refluxo, e para verificar a especificidade desses sintomas para a doença não-erosiva. Métodos: Estudo retrospectivo, transversal, com base em informações obtidas a partir de uma base de dados digital em um hospital brasileiro no período de março/outubro de 2012. A amostra foi composta por indivíduos não tratados previamente, não fumantes, >18 anos, com sintomas sugestivos de doença do refluxo, mas sem erosões esofágicas submetidos à endoscopia digestiva alta e biópsia de esôfago distal. Resultados: A amostra final incluiu 23 indivíduos. A alteração mais frequente foi invisibilidade dos vasos $(n=21 ; 91,3 \%)$, seguido por espessamento de mucosa $(n=15 ; 65,2 \%)$ e cardite $(n=5 ; 21,7 \%)$. O coeficiente de correlação entre cada variável e o diagnóstico anatomopatológico foi 0,386 para o índice de massa corporal, 0,479 para espessamento de mucosa, $-0,116$ para a invisibilidade de vasos, 0,306 para carditis e 0,462 para hérnia hiatal. Conclusão: Todos os pacientes apresentaram alterações endoscópicas mínimas, mas apenas espessamento da mucosa revelou correlação moderadamente significativa com a gravidade da esofagite, apesar do aumento dos valores no índice de massa corporal e da presença de hérnia hiatal também estarem associados.

\section{INTRODUCTION}

G astroesophageal reflux may be defined as the unimpeded traveling back of gastric contents into the esophagus. It can affect indiscriminately all individuals and may occur several times a day, especially after meals. When the duration is short, with no symptoms or signs of mucosal injury, it may be considered a physiological process.

Gastroesophageal reflux disease (GERD) is defined by the International Consensus of Montreal (2006) as "a condition that develops when the reflux of stomach contents causes troublesome symptoms and/or complications"23. GERD is highly prevalent around the world. In Brazil, 11.9\% of the population is affected, and the prevalence is expected to increas $\mathrm{e}^{18}$. Chronic GERD is associated with high levels of morbidity, frequent recurrence and loss of quality of life. The condition has several clinical presentations, regardless of gender and age, and produces a considerable economic impact, mostly due to expenditure on clinical and laboratory examinations ${ }^{21}$. 
Diagnosis requires detailed clinical history-taking and complementary tests. When suspecting GERD, the first test performed is usually esophagogastroduodenoscopy (EGD), a relatively simple procedure which allows to directly visualize the upper digestive tract and helps rule out other and more severe gastrointestinal diseases ${ }^{17}$. Confirmed by the presence of mucosal erosions, GERD is classified as erosive and subclassified according to the Los Angeles or the Savary-Miller classification ${ }^{12}$. However, endoscopic classifications merely distinguish between erosive and non-erosive esophagitis, but do not take into account the minimal changes observed in patients with non-erosive disease.

Between $50-75 \%$ of individuals with signs and symptoms suggestive of GERD display no visible erosions on EGD. In the absence of diagnostic confirmation, non-erosive reflux disease (NERD) is usually suspected ${ }^{12,16,17}$. In such patients, diagnosis requires esophageal $\mathrm{pH}$ testing, esophageal biopsy and, in some cases, esophageal impedance-pH testing ${ }^{5,21}$. Currently, NERD is distinguished from erosive esophagitis by conventional white-light EGD and distinguished from functional heartburn by esophageal $\mathrm{pH}$ testing, with or without impedancemetry.

Anatomopathological analysis of esophageal biopsies may be used to confirm GERD microscopically, ${ }^{5,21}$. Advances in EGD technology have made it possible to identify previously undetectable changes potentially associated with nonerosive disease. However, according to most studies, minimal changes (e.g. erythema, friability and edema) often display low specificity for NERD as they may also result from nonpathological factors, such as smoking ${ }^{15}$.

The need for standardizing the endoscopic diagnosis of GERD recently led to the introduction of a classification for "minimal change esophagitis", which, in the absence of erosions, categorizes subtle changes in the mucosa. However, it remains to be determined whether these changes are specific for NERD or occasional endoscopic findings. In patients with it, the most common endoscopic findings are erythema without clear demarcation, edema, whitish mucosa near the esophagogastric junction, carditis, invisibility of vessels and thickening of the mucosa ${ }^{3,4,9,10,11,15,16}$

The purpose of the present study was to evaluate the correlation between minimal endoscopic changes on whitelight EGD (carditis, mucosal thickening and invisibility of vessels) and histological changes observed in distal esophageal biopsies in a sample of patients with symptoms suggestive of GERD, and verify the specificity of these symptoms for NERD.

\section{METHODS}

The study protocol was previously submitted to and approved by the research ethics committee at UNIOESTE (Universidade Estadual do Oeste do Paraná, Brazil) through Plataforma Brasil and filed with CONEP (National Research Ethics Commission) under entry \#677.818.

Retrospective and cross-sectional, the study included previously untreated non-smoking patients aged 18-75 years with symptoms suggestive of GERD. The patients were submitted to EGD and distal esophageal biopsy. Subjects displaying esophageal erosions (characteristic of erosive GERD) or other esophageal disease (e.g. megaesophagus and caustic lesions) and subjects with history of treatment with proton pump inhibitors were excluded from the sample. Patient data were retrieved from a digital database at Gastroclínica Cascavel (Cascavel, PR, Brazil) covering the period from March to October, 2012.

Information was collected on age, gender, weight, height, body mass index (BMI), symptoms (heartburn, heartburn, regurgitation, eructation and halitosis) and endoscopic changes (hiatal hernia, enlargement of the esophageal hiatus, gastritis and duodenitis). Endoscopic findings included mucosal thickening, invisibility of vessels, carditis and absence of changes. Finally, white-light EGD findings were compared to distal esophageal biopsy findings.

Mucosal thickening is characterized by longitudinal folds separated by ridges. Invisibility of vessels is due to the disappearance of the habitual esophageal vascular network. Carditis is the presence of clearly visible vascularization and epithelial irregularities on the gastric side of the esophagogastric junction.

All endoscopies were performed by the same professional. The distal esophageal biopsies were collected at $2 \mathrm{~cm}$ above the squamocolumnar junction and analyzed by a single pathologist blinded to EGD findings, then classified according to the criteria proposed by Faramarz Ismail-Beigi (1970) ${ }^{7}$.

Using the statistics software Prism 5.0, the data were analyzed with Student's test and/or the chi-square test, and Spearman correlation coefficients were calculated. The level of statistical significance was set at $5 \%(p<0.05)$. Spearman correlation coefficients lie in the range between -1 and 1 . A negative sign indicates an inverse correlation between variables. These findings were interpreted using the classification proposed by Godeardo Baquero: -1: perfect negative correlation; -0.99 to -0.90 : very strong negative correlation; -0.89 to -0.70 : strong negative correlation; -0.69 to -0.40 : moderate negative correlation; -0.39 to -0.20: weak negative correlation; -0.19 to 0.10 : very weak negative correlation; 0 no correlation; 0.10 to 0.19 : very weak positive correlation; 0.20 to 0.39 : weak positive correlation; 0.40 to 0.69 : moderate positive correlation; 0.70 to 0.89 : strong positive correlation; 0.90 to 0.99 : very strong positive correlation; 1: perfect positive correlation.

\section{RESULTS}

No distal esophageal biopsy results were available for four of the original sample of 27 patients with symptoms suggestive of GERD, leaving a final sample 23 subjects aged $37.65 \pm 13.61$ years (range: $19-74$ ), of whom eight (34.8\%) were female and 15 (65.2\%) male. The average BMI was $25.28 \pm 3.63$ (females: 22.89 \pm 3.28 ; males: $26.55 \pm 3.21$ ). Weight, height and BMI were significantly greater for men than for women.

The most commonly reported symptoms were heartburn and regurgitation (both $n=14 ; 60.9 \%$ ), followed by early feeling of fullness $(n=8 ; 34.8 \%)$, heartburn $(n=7 ; 30.4 \%)$, nausea $(n=6 ; 26.1 \%)$ diarrhea $(n=4 ; 17.4 \%)$ and eructation $(n=1 ; 4.3 \%)$ (Table 1$)$.

TABLE 1 - Absolute and relative frequency of symptoms of non-erosive reflux disease $(n=23)$

\begin{tabular}{|c|c|c|}
\hline Symptoms & Yes n (\%) & No n (\%) \\
\hline Heartburn & $14(60.9 \%)$ & $9(39.1 \%)$ \\
\hline Bloating & $8(34.7 \%)$ & $15(65.3 \%)$ \\
\hline Eructation & $1(4.3 \%)$ & $22(95.7 \%)$ \\
\hline Diarrhea & $4(17.3 \%)$ & $19(82.7 \%)$ \\
\hline Halitosis & $0(0 \%)$ & $23(100 \%)$ \\
\hline Nausea & $6(26.1 \%)$ & $17(73.9 \%)$ \\
\hline Pyrosis & $7(30.4 \%)$ & $16(69.6 \%)$ \\
\hline Regurgitation & $14(60.9 \%)$ & $9(39.1 \%)$ \\
\hline
\end{tabular}

All patients displayed minimal endoscopic changes on EGD. The most frequently observed was invisibility of vessels $(n=21 ; 91.3 \%)$, followed by mucosal thickening $(n=15 ; 65.2 \%)$ and carditis ( $n=5 ; 21.7 \%)$ (Table 2). 
TABLE 2 - Absolute and relative frequency of minimal endoscopic changes on esophagogastroduodenoscopy with suspicion of non-erosive reflux disease $(n=23)$.

\begin{tabular}{|c|c|c|}
\hline Changes on endoscopy & Present $\mathbf{n}(\%)$ & Absent $\mathbf{n}(\%)$ \\
\hline Invisibility of vessels & $21(91.3 \%)$ & $2(8.7 \%)$ \\
\hline Carditis & $5(21.7 \%)$ & $18(78.3 \%)$ \\
\hline Mucosal thickening & $15(65.3 \%)$ & $8(34.8 \%)$ \\
\hline
\end{tabular}

Likewise, all patients displayed changes in the anatomopathological analysis. The most frequent diagnosis was mild esophagitis ( $n=16 ; 66.6 \%)$, followed by moderate esophagitis $(n=6 ; 25 \%)$ and eosinophilic esophagitis $(n=2$; $8.33 \%$ ). One patient had both moderate esophagitis and eosinophilic esophagitis (Table 3).

TABLE3-Absoluteandrelativefrequencyofanatomopathological diagnosis of esophagitis with suspicion of nonerosive reflux disease $(n=23)$

\begin{tabular}{|c|c|}
\hline Diagnosis & $\mathrm{n}(\%)$ \\
\hline Normal & $0(0 \%)$ \\
\hline Mild esophagitis & $16(66.6 \%)$ \\
\hline Moderate esophagitis & $6(25 \%)$ \\
\hline Eosinophilic esophagitis & $2(8.33 \%)$ \\
\hline
\end{tabular}

On EGD, 17 (73.9\%) subjects displayed mild enlargement of the esophageal hiatus while eight (34.8\%) had small hiatal hernias $(2-3 \mathrm{~cm})$. Enanthematous gastritis was observed in 13 (56.5\%), erosive gastritis in nine (39.1\%) and duodenitis in one (4.3\%) subject. Only one (4.3\%) patient presented no gastritis.

The presence of hiatal hernia and mucosal thickening was only moderately correlated with anatomopathological diagnosis. Despite the small correlation coefficient $(0.386)$, BMI was significantly and positively $(p=0.034)$ associated with severity of esophagitis. Mucosal thickening presented a moderate $(0.479)$ but significant $(p=0.021)$ correlation with anatomopathological diagnosis, indicating that $22.4 \%$ of the increase in severity could be explained by mucosal thickening. The remaining minimal endoscopic changes were not significantly correlated with distal esophageal biopsy results. Despite being the most frequently observed endoscopic change, invisibility of vessels presented a weak negative coefficient $(-0.116)$, suggesting an inverse relationship between the variables $(p=0.599)$. Likewise, the coefficient of carditis was weak (0.306) and non-significant $(p=0.155)$. On the other hand, hiatal hernia was moderately and significantly correlated with severity of esophagitis $(0.462 ; p=0.026)$, indicating that in $21.34 \%$ of cases, increased severity might be attributed to the presence of this condition.

\section{DISCUSSION}

The association between BMI and GERD symptoms observed in this study is supported by findings from other studies $^{19,20}$. In a Japanese paper, patients with low weight $(\mathrm{BMI}<18.5)$ and excessive weight $(\mathrm{BMI} \geq 25.0)$ were found to be at higher risk for NERD than individuals in the normal BMI range ${ }^{14}$. High BMI values have also been associated with more severe endoscopic changes ${ }^{24}$. This is supported by the reported predominance of individuals with excess weight among erosive GERD patients ${ }^{1,2}$. Other authors have reported negative correlations between BMI and NERD: the condition was more prevalent in patients with low $\mathrm{BMI}^{6}$ or $\mathrm{BMI}$ values under $23^{12}$.

The high incidence of inflammation of the gastric mucosa and the finding of only one patient in this sample without gastritis on EGD suggest a close association between gastritis and esophagitis. The severity of gastritis has been associated with the presence of Helicobacter pylori although the present study was not designed to evaluate this hypothesis. According to Kandulski and Malfertheiner ${ }^{8}$, infection by strains of Cag A-positive $H$. pylori appears to protect the distal esophagus against exposure to abnormal acid levels by way of fundic gland atrophy. Nevertheless, despite reports suggesting the development of erosive esophagitis following the eradication of $H$. pylori; more recent studies have concluded that eradication has no significant clinical impact on GERD.

According to Kim et al. ${ }^{10}$, certain minimal endoscopic changes are associated with NERD. Thus, in their sample, mucosal thickening, carditis and irregularities in the esophagogastric junction were significantly more common in patients with NERD, although the association was only independent for mucosal thickening (OR 3.97; 95\% CI: 1.72-9.13). In this study, the only endoscopic change significantly correlated with severity of esophagitis was mucosal thickening (observed in over half of these patients). The correlation was non-significant for all other changes, even for the highly prevalent finding "invisibility of vessels". However, due to the small sample size and the exclusion of other causes of esophageal injury (such as smoking), mucosal thickening could not be identified as a symptom specific for NERD. Likewise, due to low sensitivity and specificity, not find mucosal thickening to be a reliable diagnostic marker for NERD, but in patients with hiatal hernia, changes in mucosal thickness seem to be a useful indicator of esophagitis.

Eosinophilic esophagitis, an allergic condition of probable genetic cause, affects young adults with a history of persistent symptoms of dysphagia or GERD. According to some reports, in up to $40 \%$ of patients with eosinophilic esophagitis, the condition is associated with GERD. Reflux is believed to lead to allergy-like inflammation by increasing the number of eosinophils in the mucosa of the lower esophagus. Half of GERD patients may display infiltration of eosinophils in the distal esophagus, but the number of eosinophils is small and only the lower part of the organ is affected. Such patients may have normal EGD findings or changes not specific for the condition, making diagnosis by endoscopy inconclusive until biopsy results become available. In the present study, two patients were diagnosed with eosinophilic esophagitis.

Distal esophageal biopsies not only help confirm the diagnosis of esophagitis, but allow to establish differential diagnosis ruling out other diseases of the uppergastrointestinal tract.

\section{CONCLUSION}

All the patients this sample with symptoms suggestive of GERD had minimal endoscopic changes on white-light EGD and had biopsies positive for esophagitis. However, only mucosal thickening displayed moderately significant correlation with severity of esophagitis in patients with NERD, although increased BMI values and the presence of hiatal hernia were also associated. Due to the small sample size and the exclusion of other causes of esophageal injury (such as smoking), mucosal thickening could not be identified as a specific alteration for NERD. 


\section{REFERENCES}

1. Ang TL, Fock KM, Ng TM, Teo EK, Chua TS, Tan J. A comparison of the clinical, demographic and psychiatric profiles among patients with erosive and non-erosive reflux disease in a multi-ethnic Asian country. World J Gastroenterol. 2005 Jun 21;11(23):3558-61.

2. Biccas BN, Lemme EMO, Abrahão Jr LJ, Aguero GC, Alvariz AC, Schechter RB. Higher prevalence of obesity in erosive gastroesophageal reflux disease. Arq Gastroenterol. 2009;46(1): 15-9.

3. Caviglia R, Ribolsi M, Gentile M, Rabitti C, Emerenziani S, Guarino MP, Petitti T, Cicala M. Dilated intercellular spaces and acid reflux at the distal and proximal oesophagus in patients with non-erosive gastro-oesophageal reflux disease. Aliment Pharmacol Ther. 2007 Mar 1;25(5):629-36.

4. Chu CL, Zhen YB, Lv GP, Li CQ, Li Z, Qi QQ, Gu XM, Yu T, Zhang TG, Zhou CJ, Rui-Ji, Li YQ. Microalterations of esophagus in patients with non-erosive reflux disease: in-vivo diagnosis by confocal laser endomicroscopy and its relationship with gastroesophageal reflux. Am J Gastroenterol. 2012 Jun;107(6):864-74.

5. Federação Brasileira de Gastroenterologia, Sociedade Brasileira de Endoscopia Digestiva, Colégio Brasileiro de Cirurgia Digestiva, Sociedade Brasileira de Pneumologia e Tisiologia. Doença do refluxo gastroesofágico: diagnóstico. Diretrizes em foco; Rev Assoc Med Bras. 2011. 57(5):499-507.

6. Fujiwara Y, Arakawa T. Epidemiology and clinical characteristics of GERD in the Japanese population. J Gastroenterol. 2009;44(6):518 34.

7. Ismail-Beigi F, Horton PF, Pope CE 2nd.Histological consequences of gastroesophageal reflux in man. Gastroenterology. 1970 Feb;58(2):163-74.

8. Kandulski A, Malfertheiner P. Helicobacter pylori and gastroesophageal reflux disease. Curr Opin Gastroenterol. 2014 Jul:30(4):402-7.

9. Kasap E, Zeybel M, Aşık G, Ayhan S, Yüceyar H. Correlation among standard endoscopy, narrow band imaging, and histopathological findingsinthe diagnosis of nonerosive refluxdisease.J Gastrointestin Liver Dis. 2011 Jun;20(2):127-30.

10. Kim JB, Shin SR, Shin WG, Choi MH, Jang HJ, Kim KO, Park CH, Baek IH, Baik GH, Kim KH, Park SH, Kae SH, Lee MS, Kim HY. Prevalence of minimal change lesions in patients with non-erosive reflux disease: a case-control study. Digestion. 2012;85(4):288-94

11. Kim JH, Park H, Lee YC; MIGHT study group. Is minimal change esophagitis really part of the spectrum of endoscopic findings of gastroesophageal reflux disease? A prospective, multicenter study. Endoscopy. 2011 Mar;43(3):190-5.

12. Kim N, Lee SW, Cho SI, Park CG, Yang CH, Kim HS, Rew JS, Moon JS, Kim S, Park SH, Jung HC, Chung IS; H. pylori and Gerd Study Group of Korean College of Helicobacter and Upper Gastrointestinal Research. The prevalence of and risk factors for erosive oesophagitis and non-erosiverefluxdisease: a nationwidemulticentre prospective study in Korea. Aliment Pharmacol Ther. 2008 Jan 15;27(2):173-85.
13. Lundell LR, Dent J, Bennett JR, Blum AL, Armstrong D, Galmiche JP, Johnson F, Hongo M, Richter JE, Spechler SJ, Tytgat GN, Wallin L. Endoscopic assessment of oesophagitis: clinical and functional correlates and further validation of the Los Angeles classification Gut. 1999 Aug;45(2):172-80.

14. Minatsuki $C$, Yamamichi N, Shimamoto $T$, Kakimoto $H$, Takahashi $Y$ Fujishiro M, Sakaguchi Y, Nakayama C, Konno-Shimizu M, Matsuda R, Mochizuki S, Asada-Hirayama I, Tsuji Y, Kodashima S, Ono S, Niimi K, Mitsushima T, Koike K. Background factors of reflux esophagitis and non-erosive reflux disease: a cross-sectional study of 10,837 subjects in Japan. PLoS One. 2013 Jul 26;8(7):e69891.

15. Miyasaka M, Hirakawa M, Nakamura K, Tanaka F, Mimori K, Mori $\mathrm{M}$, Honda $\mathrm{H}$. The endoscopic diagnosis of nonerosive reflux disease using flexible spectral imaging color enhancement image: a feasibility trial. Dis Esophagus. 2011 Aug;24(6):395-400.

16. Modlin IM, Hunt RH, Malfertheiner P, Moayyedi P, Quigley EM, Tytgat GN, Tack J, Heading RC, Holtman G, Moss SF; Vevey NERD Consensus Group. Diagnosis and management of non-erosive reflux disease-the Vevey NERD Consensus Group. Digestion. 2009;80(2):74-88.

17. Moraes-Filho J, Cecconello I, Gama-Rodrigues J, Castro L, Henry MA, Meneghelli UG, Quigley E; Brazilian Consensus Group. Brazilian consensus on gastroesophageal reflux disease: proposals for assessment, classification, and management. Am J Gastroenterol. 2002 Feb;97(2):241-8.

18. Moraes-Filho JPP, Chinzon D, Eisig JN, Hashimoto CL, Zaterka S. Prevalência da pirose e da doença gastroesofágica numa população urbana brasileira. Arq Gastroenterol 2004; 42(2):122-7.

19. Murray L, Johnston B, Lane A, Harvey I, Donovan J, Nair P, Harvey R. Relationship between body mass and gastro-oesophageal reflux symptoms: The Bristol Helicobacter Project. Int J Epidemiol. 2003 Aug;32(4):645-50.

20. Nandurkar S, Locke GR 3rd, Fett S, Zinsmeister AR, Cameron AJ, Talley NJ. Relationship between body mass index, diet, exercise and gastro-oesophageal reflux symptoms in a community. Aliment Pharmacol Ther. 2004 Sep 1;20(5):497-505.

21. Nwokediuko SC. Current trends in the management of gastroesophageal reflux disease: a review. ISRN Gastroenterol. 2012;2012:391631.

22. Silva MC, Carlos AS, Montes CG, Zeitune JMR. Esofagite eosinofílica em adultos: (revisão). RBM rev. bras. med. set 2008; 65(9):273-278

23. Vakil N, van Zanten SV, Kahrilas P, Dent J, Jones R; Global Consensus Group.The Montreal definition and classification of gastroesophageal reflux disease: a global evidence-based consensus. Am J Gastroenterol. 2006 Aug;101(8):1900-20; quiz 1943.

24. Zafar S, Israr ul Haq, Butt AR, Shafiq F, Mirza HG, Ameed-ur-Rehman. Correlation of endoscopic severity of Gastroesophageal Reflux Disease (GERD) with Body Mass Index (BMI). J Coll Physicians Surg Pak. 2007 Feb;17(2):72-5. 